\title{
Ibu hamil perokok pasif sebagai faktor risiko bayi berat lahir rendah
}

\author{
Passive smoker pregnant mother as risk factor for low birth weight babies
}

Irnawati ${ }^{1}$,Mohammad Hakimi², Tunjung Wibowo ${ }^{3}$

\begin{abstract}
Background: Low birth weigth babies (LBW) are most likely a cause of the infant mortality and morbidity. Many factors causes $L B W$ babies as maternal health, behavior during pregnancy, environmental as well as fetal and placental factors. Negative behavior during pregnancy such as exposure of cigarette smoke can affect the body's supply of oxygen from mother to fetus and placenta. Exposure to cigarette smoke may also reduce maternal folic acid level which causes disruption of fetal growth inside the womb.

Objective: This study was aimed to find out the risk of low birth weight baby in the passive smoker pregnant woman. Method: The study used a case control design. The subject consisted of mothers who delivered at RSU dr. Zainoel Abidin in Banda Aceh municipality. The case group were mothers who delivered babies of less than 2,500 grams and the control group were those who delivered babies of 2,500 grams or more. Each group consisted of 105 mothers (1:1). Sample were taken using non probability with consecutive sampling method. Data analysis used univariable method with frequency distribution, bivariable with chi square and multivariable with logistic regression.

Results: Passive smoker pregnant woman exposed the 1-10 cigarettes a day had risk 2,4 times greater of getting low birth weight baby $(O R=2,42 ; 95 \% \mathrm{Cl} 1,24-4,71)$. Pregnant mother exposed to $\geq 11$ cigarettes a day had the risk 3,1 times greates in having LBW infants than those not exposed (OR=3,1;95\% Cl 1,50-6,70).

Conclusion: Passive smoker of pregnant mother increased the risk of low birth weight babies.
\end{abstract}

KEY WORDS risk, low birth weight baby, passive smoker, pregnant woman

\begin{abstract}
ABSTRAK
Latar belakang: Bayi berat lahir rendah merupakan penyumbang terbesar kematian dan kesakitan bayi. Kejadian bayi berat lahir rendah berhubungan dengan banyak faktor seperti faktor kesehatan ibu, perilaku selama hamil, lingkungan serta faktor janin dan plasenta. Perilaku yang buruk selama kehamilan seperti paparan asap rokok dapat mempengaruhi suplai oksigen dari tubuh ibu ke janin dan plasenta. Paparan asap rokok juga dapat menurunkan kadar asam folat ibu yang berakibat terganggunya pertumbuhan janin di dalam kandungan.

Tujuan: Mengetahui risiko terjadinya bayi berat lahir rendah pada ibu hamil perokok pasif.

Metode: Jenis penelitian observasional dengan desain studi kasus kontrol. Subjek penelitian adalah ibu yang melahirkan di BPK RSU dr. Zainoel Abidin di Kota Banda Aceh. Subjek penelitian pada kelompok kasus adalah ibu yang melahirkan bayi di bawah $2.500 \mathrm{~g}$. Ibu yang melahirkan bayi lebih atau sama dengan $2.500 \mathrm{~g}$ akan menjadi kelompok kontrol. Jumlah subjek untuk masing-masing kelompok sebesar 105 (1:1). Pengambilan sampel menggunakan teknik non probability sampling dengan metode consecutive sampling. Analisis data secara univariat menggunakan distribusi frekuensi, bivariat menggunakan Chi-square, dan multivariat menggunakan regresi logistik.

Hasil: Hasil penelitian menggambarkan ibu hamil perokok pasif yang terpapar asap rokok 1-10 batang per hari berisiko 2,4 kali lebih sering untuk terjadinya bayi berat lahir rendah $(B B L R)$ dengan $O R=2,42 ; 95 \% C l=1,24-4,71$. Ibu hamil yang terpapar asap rokok lebih dari atau sama dengan 11 batang per hari berisiko 3,1 kali lebih sering mengalami BBLR dibanding ibu yang tidak terpapar (OR=3,1; 95\% Cl=1,50-6,70).

Kesimpulan: Ibu hamil perokok pasif dapat meningkatkan risiko terjadinya bayi berat lahir rendah.
\end{abstract}

KATA KUNCI: risiko, bayi berat lahir rendah, perokok pasif, ibu hamil

\section{PENDAHULUAN}

Bayi berat lahir rendah (BBLR) adalah bayi dengan berat lahir kurang dari 2500 gram yang ditimbang dalam satu jam setelah lahir tanpa memandang masa gestasi (1). Prevalensi BBLR di seluruh dunia diperkiraan 15\% dari seluruh kelahiran. Lebih dari $97 \%$ terjadi di negara berkembang atau sosial ekonomi rendah (2). Di Indonesia prevalensi BBLR berkisar 7,5\% (3).
Penyebab BBLR adalah riwayat prematur dan BBLR sebelumnya, faktor janin dan plasenta, usia ibu, paritas,

\footnotetext{
${ }^{1}$ Poltekkes Kemenkes Aceh Jurusan Kebidanan, Jl. Tsyarief Thayeb Lamprit, Banda Aceh, e-mail: irnadarwin@yahoo.co.id

2 Magister Kesehatan Ibu dan Anak-Kesehatan Reproduksi (KIA-KR), Fakultas Kedokteran Universitas Gadjah Mada, Jl. Farmako, Sekip Utara, Yogyakarta 55281, e-mail: moh.hakimi@yahoo.co.id

${ }^{3}$ Bagian Obsetri dan Ginekologi RSUP Dr. Sardjito, JI. Kesehatan, Yogyakarta 55281
} 
pekerjaan ibu, status gizi, penyakit ibu seperti malaria, anemia, sipilis, TORCH (toxoplasma, rubella, Cyto Megalo Virus/CMV, herpes), dan komplikasi pada kehamilan (perdarahan antepartum, pre-eklamsia). Penyebab lain yaitu faktor pengetahuan, pendidikan, perilaku ibu hamil seperti perokok aktif dan pasif, pengguna narkoba, alkohol, faktor lingkungan tempat tinggal serta paparan zat-zat racun (4).

BBLR 40 kali berisiko mengalami kematian. Komplikasi yang ditimbulkan antara lain: hipotermia, hipoglikemia, gangguan cairan dan elektrolit, paten duktus arteriosus, infeksi, perdarahan intraventrikuler, dan apnoe. Selanjutnya akan mengalami gangguan perkembangan dan pertumbuhan, gangguan penglihatan, gangguan pendengaran, penyakit paru kronis yang berakibat pada peningkatan mortalitas, serta tingginya biaya perawatan yang dibutuhkan (5).

Banyak upaya yang telah dilakukan untuk menurunkan prevalensi BBLR di Indonesia seperti pemeriksaan kehamilan minimal 4 kali selama kehamilan, pemantauan faktor risiko, perencanaan kehamilan dalam kurun waktu reproduksi sehat (usia 20-34 tahun), dan pendidikan kesehatan bagi calon ibu. Namun upaya yang telah dilakukan belum menunjukkan hasil maksimal (6). Tantangan yang dihadapi untuk menurunkan prevalensi BBLR adalah cara memperbaiki perilaku keluarga dan masyarakat, terutama perilaku hidup bersih dan sehat selama kehamilan seperti mengindari asap rokok pada wanita hamil (7).

Hasil penelitian di Yogyakarta pada tahun 2006 menyatakan bahwa subjek dengan berat badan lahir lebih dari atau sama dengan 2500 g mempunyai skor kecerdasan 6,51 poin lebih tinggi dibandingkan subjek dengan berat badan lahir kurang dari $2500 \mathrm{~g}$ (8). Hasil penelitian tersebut didukung oleh penelitian di Belanda yang menyimpulkan bahwa anak dengan berat badan lahir sangat rendah jika diberi stimulasi yang baik dari lingkungan maka perkembangan kognitif dapat meningkat (9).

Perokok pasif adalah penduduk yang bukan perokok, namun tinggal serumah dengan perokok aktif yang merokok di dalam rumah (10). Prevalensi perokok aktif di provinsi Aceh mencapai $80,2 \%$ penduduk dan $95 \%$ perokok aktif tersebut merokok di dalam rumah (11). Lingkungan berasap tembakau mengandung lebih dari 4000 senyawa kimia. Tiga komponen toksik yang utama adalah karbonmonoksida (CO), nikotin $\left(\mathrm{C}_{10} \mathrm{H}_{14} \mathrm{~N}_{2}\right)$, dan tar. Karbonmonoksida yang terabsorbsi ke dalam tubuh ibu secara langsung akan mengikat hemoglobin ( $\mathrm{Hb}$ ). $\mathrm{Hb}$ memiliki kemampuan mengikat $\mathrm{CO}$ jauh lebih besar dibandingkan dengan kemampuannya mengikat oksigen $\left(\mathrm{O}_{2}\right)$, sehingga kapasitas $\mathrm{O}_{2}$ di dalam darah akan berkurang. Efeknya bagi janin lebih berbahaya dari pada ibu karena janin menerima $\mathrm{O}_{2}$ lebih sedikit. Nikotin merupakan vasokonstriktor yang dapat menurunkan perfusi plasenta dan menurunkan penerimaan $\mathrm{O}_{2}$ bagi janin (12).

Paparan asap pembakaran tembakau juga menurunkan $20 \%$ kadar asam folat di dalam tubuh (13). Sehingga paparan asap tembakau pada ibu hamil menyebabkan gangguan pertumbuhan janin di dalam kandungan (14). Penelitian terdahulu menunjukkan paparan asap rokok pada ibu selama hamil dapat meningkatkan kelahiran BBLR (OR=1,29, 95\%Cl:1,061,57) (15). Selain itu paparan asap rokok selama kehamilan juga dapat meningkatkan kongenital anomali (OR=1,17; 95\%Cl:1,03-1,34) (16) dan kematian janin dalam kandungan $(95 \% \mathrm{Cl}: 1,0-6,9)(17)$.

Tujuan penelitian ini adalah mengetahui besarnya pengaruh jumlah rokok yang dihisap di dalam rumah terhadap risiko terjadinya bayi berat lahir rendah, dan besarnya pengaruh tingkat pendidikan, status bekerja, status gizi, riwayat BBLR terdahulu, dan umur ibu hamil perokok pasif terhadap risiko bayi berat lahir rendah.

\section{BAHAN DAN METODE}

Jenis penelitian ini adalah penelitian observasional dengan rancangan case control. Populasi penelitian adalah ibu bersalin yang ada di Badan Pelayanan Kesehatan (BPK) RSU Dr. Zainoel Abidin di Kota Banda Aceh pada Januari 2005 sampai dengan Februari 2007. Besar sampel dihitung dengan rumus untuk menguji hipotesis terhadap odds-ratio (18) dengan proporsi ibu hamil perokok pasif pada kelompok kontrol sebesar 0,46; proporsi ibu hamil perokok pasif pada kelompok kasus sebesar 0,65; OR=2,2 (17); tingkat kepercayaan $95 \%$; dan kekuatan uji sebesar $80 \%$.

Besar sampel adalah 105 responden pada kelompok kasus dan 105 responden pada kelompok kontrol (1:1). Kelompok kasus adalah ibu yang melahirkan bayi di bawah 2500 g. Kelompok kontrol adalah ibu yang melahirkan bayi dengan berat lebih atau sama dengan $2500 \mathrm{~g}$ dalam periode yang sama dengan kelompok kasus yaitu Januari 2005 sampai dengan Februari 2007. Kriteria inklusi dalam penelitian ini meliputi: bersalin di rumah sakit, usia kehamilan saat persalinan lebih dari atau sama dengan 36 minggu, dan bersedia menjadi responden penelitian. Kriteria eksklusi: ibu menderita penyakit kronis sebelum dan selama hamil, ibu dengan persalinan kembar.

Teknik pengambilan sampel secara non probability sampling, dengan metode consecutive sampling. Data berat bayi lahir diperoleh dari rekam medis pasien yang ada di rumah sakit. Kuesioner digunakan untuk mengetahui data pribadi responden, jumlah perokok di dalam rumah, dan jumlah rokok yang dihisap. Kuesioner diadopsi dari Jarvis (19). Data dikumpulkan oleh 5 orang enumerator yaitu mahasiswa DIII kebidanan semester 5 yang telah dilatih untuk membantu pengumpulan data.

Variabel-variabel yang diteliti meliputi variabel terikat yaitu BBLR adalah bayi baru lahir dengan berat kurang dari $2500 \mathrm{~g}$. Variabel bebas yaitu ibu hamil perokok pasif yang dilihat dari jumlah rokok yang dihisap di dalam rumah oleh masing-masing perokok aktif per hari. Jumlah batang rokok dihitung dari penjumlahan rokok yang dihisap oleh masing- 
masing perokok aktif per hari. Variabel lain yang ikut diteliti meliputi: pendidikan ibu yaitu pendidikan formal yang telah ditempuh oleh ibu hamil dengan kriteria tinggi bila S1/S2, D3 atau SMA, rendah bila SMP, SD dan tidak sekolah; status pekerjaan ibu yaitu pekerjaan rutin yang dilakukan ibu di luar rumah selain pekerjaan ibu sebagai rumah tangga; umur ibu yaitu umur ibu pada saat melahirkan dengan kriteria tidak berisiko bila umur antara 20-33 tahun dan berisiko bila umur kurang dari 19 tahun atau lebih dari atau sama dengan 34 tahun; status gizi ibu yaitu keadaan gizi ibu selama hamil dengan mengukur lingkar lengan atas (LLA) dengan kategori gizi baik bila LLA lebih dari atau sama dengan $23,5 \mathrm{~cm}$ dan gizi buruk bila LLA kurang dari $23,5 \mathrm{~cm}$; riwayat BBLR sebelumnya yaitu ibu bersalin yang mempunyai riwayat pernah melahirkan bayi dengan berat di bawah 2500 g pada persalinan sebelumnya.

Data dianalisis secara bivariat untuk melihat kemaknaan hubungan antara variabel terikat dengan variabel bebas serta variabel luar dengan uji statistik regresi logistik, dihitung odd rasio dan interval kepercayaan (IK) $95 \%$. Variabel yang diikutsertakan pada analisa multivariat ini adalah variabel bebas dan variabel luar yang memiliki nilai p kurang dari 0,25 (20).

\section{HASIL}

\section{Karakteristik subjek}

Distribusi frekuensi karakteristik subjek penelitian dapat dilihat pada Tabel 1.
Tabel 1. Distribusi frekuensi karakteristik subjek

\begin{tabular}{|c|c|c|c|c|}
\hline \multirow{2}{*}{ Variabel } & \multicolumn{2}{|c|}{ Kasus } & \multicolumn{2}{|c|}{ Kontrol } \\
\hline & $\mathbf{n}$ & $\%$ & $\mathbf{n}$ & $\%$ \\
\hline \multicolumn{5}{|l|}{ Pendidikan } \\
\hline SD/Mi sederajat & 9 & 8,6 & 16 & 15,2 \\
\hline SMP/MTs sederajat & 23 & 21,9 & 10 & 9,5 \\
\hline SMU/MA sederajat & 56 & 53,3 & 67 & 63,8 \\
\hline Akademi/D3 sederajat & 13 & 12,4 & 7 & 6,7 \\
\hline S1/S2 & 14 & 3,8 & 5 & 4,8 \\
\hline \multicolumn{5}{|l|}{ Status pekerjaan ibu } \\
\hline Bekerja & 20 & 19,0 & 11 & 10,8 \\
\hline Tidak bekerja & 85 & 81,0 & 94 & 89,5 \\
\hline \multicolumn{5}{|l|}{ Riwayat BBLR sebelumnya } \\
\hline Ada & 15 & 14,3 & 4 & 3,8 \\
\hline Tidak ada & 90 & 85,7 & 101 & 96,2 \\
\hline \multicolumn{5}{|l|}{ Umur ibu (tahun) } \\
\hline$\leq 19$ & 12 & 11,4 & 4 & 3,8 \\
\hline $20-33$ & 61 & 58,1 & 68 & 64,8 \\
\hline$\geq 34$ & 32 & 30,5 & 33 & 31,4 \\
\hline \multicolumn{5}{|l|}{ Status gizi ibu } \\
\hline Gizi buruk (LLA $\leq 23,4 \mathrm{~cm}$ ) & 7 & 6,7 & 0 & 0,0 \\
\hline Gizi baik (LLA $\geq 23,5 \mathrm{~cm}$ ) & 98 & 93,3 & 105 & 100 \\
\hline \multicolumn{5}{|l|}{ Ibu hamil perokok pasif } \\
\hline Ya & 82 & 78,1 & 61 & 58,1 \\
\hline Tidak & 23 & 21,9 & 44 & 41,9 \\
\hline \multicolumn{5}{|l|}{ Jumlah perokok di dalam rumah } \\
\hline Tidak ada & 20 & 19,0 & 44 & 41,9 \\
\hline 1 orang & 25 & 23,8 & 48 & 45,7 \\
\hline$\geq 2$ orang & 60 & 57,1 & 13 & 12,4 \\
\hline \multicolumn{5}{|l|}{ Jumlah rokok yang dihisap } \\
\hline Tidak ada & 23 & 21,9 & 46 & 43,8 \\
\hline $1-10$ batang & 47 & 44,8 & 38 & 36,2 \\
\hline$\geq 11$ batang & 35 & 33,3 & 21 & 20,0 \\
\hline
\end{tabular}

Keterangan: BBLR : bayi berat lahir rendah LLA : lingkar lengan atas

Tabel 2. Analisis bivariat antara variabel terikat dengan variabel luar

\begin{tabular}{|c|c|c|c|c|c|c|}
\hline \multirow{2}{*}{ Variabel } & \multicolumn{2}{|c|}{ Kasus } & \multicolumn{2}{|c|}{ Kontrol } & \multirow{2}{*}{ OR } & \multirow{2}{*}{ IK $95 \%$} \\
\hline & $\mathbf{n}$ & $\%$ & $\mathbf{n}$ & $\%$ & & \\
\hline \multicolumn{7}{|c|}{$\begin{array}{l}\text { Jumlah rokok yang dihisap di dalam } \\
\text { rumah/hari }\end{array}$} \\
\hline Tidak ada & 23 & 21,90 & 46 & 43,81 & 1 (referensi) & \\
\hline $1-10$ batang & 47 & 44,76 & 38 & 36,19 & 2,47 & $1,28-4,77$ \\
\hline$\geq 11$ batang & 35 & 33,33 & 21 & 20,00 & 3,33 & $1,59-6,96$ \\
\hline \multicolumn{7}{|l|}{ Status pekerjaan ibu } \\
\hline Bekerja & 20 & 19,05 & 11 & 10,848 & 2,01 & $0,91-4,43$ \\
\hline Tidak bekerja & 85 & 80,95 & 94 & 9,52 & 1 (refensi) & \\
\hline \multicolumn{7}{|l|}{ Tingkat pendidikan } \\
\hline Rendah (SD,SMP) & 32 & 30,84 & 26 & 24,767 & 1,33 & $0,72-2,44$ \\
\hline Tinggi (SMU,D3,Sarjana) & 73 & 69,52 & 79 & 5,24 & 1 (refensi) & \\
\hline \multicolumn{7}{|l|}{ Umur ibu (tahun) } \\
\hline$\leq 19-\geq 34$ (berisiko) & 44 & 41,90 & 37 & 35,246 & 1,32 & $0,75-2,31$ \\
\hline 20-33 (tidak berisiko) & 61 & 58,10 & 68 & 4,76 & 1 (refensi) & \\
\hline \multicolumn{7}{|l|}{ Riwayat BBLR sebelumnya } \\
\hline Ada & 15 & 14,29 & 11 & 3,81 & 4,20 & $1,34-13,14$ \\
\hline Tidak ada & 90 & 85,71 & 94 & 96,19 & 1 (refensi) & \\
\hline \multicolumn{7}{|l|}{ Status gizi ibu } \\
\hline Buruk (LLA $<23,4 \mathrm{~cm})$ & 7 & 6,67 & 0 & 0,00 & - & - \\
\hline Baik (LLA $\geq 23,5 \mathrm{~cm})$ & 98 & 93,33 & 105 & 100 & & \\
\hline
\end{tabular}

Keterangan : BBLR : bayi berat lahir rendah

$$
\begin{array}{ll}
\text { LLA } & \text { : lingkar lengan atas } \\
\text { OR } & : \text { odd rasio } \\
\text { IK } & : \text { interval kepercayaan }
\end{array}
$$




\section{Analisis bivariat}

Analisis bivariat ditunjukkan dalam Tabel 2. Hasil perhitungan statistik menunjukkan rokok yang dihisap 1-10 batang per hari oleh perokok aktif di dalam rumah selama ibu hamil, berisiko bagi ibu hamil untuk melahirkan BBLR sebesar 2,47 kali. Paparan asap oleh perokok aktif yang merokok di dalam rumah lebih dari 11 batang, berisiko 3,33 kali lebih besar bagi ibu hamil untuk melahirkan BBLR dibandingkan dengan ibu hamil yang tidak ada perokok di dalam rumahnya. Tingkat pendidikan ibu yang rendah dan umur ibu yang berisiko ( $\leq 19$ tahun dan $\geq 34$ tahun) tidak menjadi faktor risiko bagi ibu untuk terjadinya kelahiran BBLR, sedangkan ibu yang pernah melahirkan bayi BBLR pada persalinan terdahulu memiliki risiko untuk melahirkan BBLR sebanyak 4,2 kali lebih sering dibandingkan dengan ibu yang tidak pernah melahirkan BBLR pada persalinan sebelumnya. Status gizi ibu yang buruk bukan merupakan faktor risiko untuk terjadinya BBLR.

\section{Analisis multivariat}

Model 1 pada Tabel 3 menunjukkan, dengan memperhitungkan variabel status bekerja dan riwayat BBLR terdahulu, risiko kelahiran BBLR pada ibu hamil perokok pasif yang terpapar 1-10 batang rokok per hari 2,5 kali lebih besar dibandingkan dengan ibu yang tidak terpapar dengan rokok. Namun bila jumlah rokok yang dihisap lebih dari 11 batang, risiko untuk melahirkan BBLR sebanyak 3,3 kali lebih sering dibandingkan dengan ibu yang tidak terpapar dengan asap rokok. Ibu yang bekerja pada perhitungan multivariat, dengan mempertimbangkan variabel jumlah rokok yang dihisap dan riwayat BBLR terdahulu, secara statistik tidak bermakna untuk menjadi faktor risiko kelahiran BBLR. Ibu yang pernah melahirkan BBLR sebelumnya berpeluang 3,6 kali untuk mengalami kembali kelahiran BBLR bila disertai dengan adanya perokok di dalam rumahnya.

Model 2 dibangun untuk mengetahui risiko kelahiran BBLR pada ibu hamil perokok pasif bersamaan dengan variabel riwayat BBLR terdahulu. Pada model 2 menunjukkan bahwa jumlah rokok yang dihisap di dalam rumah 1 sampai 10 batang secara statistik memberi risiko untuk kelahiran BBLR. Jumlah rokok yang dihisap di dalam rumah lebih dari 11 batang dan riwayat kelahiran BBLR sebelumnya juga menjadi faktor risiko kelahiran BBLR.

\section{BAHASAN}

Hasil uji statistik menunjukkan adanya hubungan yang bermakna antara ibu hamil perokok pasif dengan kejadian BBLR. Hasil ini sesuai dengan penelitian sebelumnya yang mendapatkan ibu hamil perokok pasif berisiko 1,8 kali untuk melahirkan BBLR (21). Kelahiran BBLR pada ibu hamil perokok pasif diakibatkan oleh paparan karbonmonoksida (CO) yang terus menerus selama ibu hamil. Karbonmonoksida (CO) dapat diikat di dalam $\mathrm{Hb}$ ibu sehingga mengakibatkan menurunnya kapasitas pengangkutan oksigen di dalam darah ibu, sehingga tubuh janin akan menerima oksigen lebih sedikit. Selain $\mathrm{CO}$, nikotin yang dihasilkan dari asap rokok perokok aktif kemudian terhisap oleh ibu hamil juga dapat menurunkan perfusi plasenta. Nikotin yang masuk ke dalam darah ibu dapat melewati plasenta dan mempengaruhi beberapa organ tubuh janin. Nikotin juga dapat menyebabkan penurunan penerimaan oksigen pada janin. Akibatnya janin akan tumbuh dengan berat di bawah normal (22).

Ibu bekerja tidak terbukti sebagai faktor pengganggu antara ibu hamil perokok pasif dengan risiko kelahiran BBLR. Hasil analisis bivariat juga menunjukkan ibu bekerja tidak mempunyai risiko terhadap kelahiran BBLR, demikian pula halnya pada analisis multivariat. Risiko kelahiran BBLR

Tabel 3. Analisis regresi logistik (perkiraan odds ratio) jumlah rokok yang dihisap di dalam rumah, status pekerjaan ibu, dan riwayat BBLR dengan risiko BBLR

\begin{tabular}{|c|c|c|c|c|}
\hline \multirow{3}{*}{ Variabel } & \multicolumn{4}{|c|}{ Risiko BBLR } \\
\hline & \multicolumn{2}{|c|}{ Model 1} & \multicolumn{2}{|c|}{ Model 2} \\
\hline & OR & IK 95\% & OR & IK 95\% \\
\hline \multicolumn{5}{|c|}{$\begin{array}{l}\text { Jumlah rokok yang dihisap } \\
\text { didalam rumah/hari }\end{array}$} \\
\hline Tidak ada* & 1 (referensi) & & 1 (referensi) & \\
\hline $1-10$ batang & $2,53^{*}$ & $1,28-4,98$ & $2,42^{*}$ & $1,24-4,71$ \\
\hline$\geq 11$ batang & $3,39^{*}$ & $1,58-7,25$ & $3,1^{*}$ & $1,50-6,70$ \\
\hline \multicolumn{5}{|l|}{ Status pekerjaan ibu } \\
\hline Tidak bekerja & 1 (referensi) & & & \\
\hline Bekerja & 2,14 & $0,92-4,98$ & & \\
\hline \multicolumn{5}{|l|}{ Riwayat BBLR } \\
\hline Tidak & 1 (referensi) & & 1 (referensi) & \\
\hline Ya & $3,62^{*}$ & $1,12-11,73$ & $3,47^{*}$ & $1,21-12,39$ \\
\hline $\mathrm{R}^{2}(\%)$ & \multicolumn{2}{|c|}{17} & \multicolumn{2}{|c|}{16} \\
\hline $\mathrm{N}$ & \multicolumn{2}{|c|}{210} & \multicolumn{2}{|c|}{210} \\
\hline
\end{tabular}

Keterangan : * signifikan $<0,05$

BBLR : bayi berat lahir rendah 
pada ibu bekerja berhubungan dengan beban kerja, aktivitas fisik saat bekerja, dan lama berdiri saat bekerja (23). Dalam penelitian ini rata-rata ibu bekerja hanya sebagai guru dan pegawai negeri yang bekerja di kantor, sehingga tidak melakukan aktivitas fisik berat yang menyebabkan kelahiran BBLR. Pekerjaan ibu yang dapat merugikan kehamilan berhubungan dengan radiasi, paparan zat-zat kimia, kebisingan, lama jam kerja, pekerjaan fisik yang berat, dan stres psikis selama bekerja (24).

Tingkat pendidikan ibu mayoritas tinggi, baik pada kelompok kasus maupun kelompok kontrol. Analisis bivariat menunjukkan bahwa tingkat pendidikan ibu yang rendah tidak berhubungan dengan risiko kelahiran BBLR. Penelitian sebelumnya yang meneliti tentang upaya pencegahan perokok pasif pada wanita hamil yang tidak merokok di Guangzhou, Cina menyatakan bahwa wanita dengan pendidikan dan pengetahuan yang tinggi 1,36 kali lebih dapat mencegah dan menghindari paparan asap tembakau, baik di rumah maupun di tempat-tempat umum (25).

Dalam penelitian ini responden dengan pendidikan yang tinggi mungkin saja tidak diiringi dengan pengetahuan yang tinggi tentang bahaya asap rokok selama kehamilan. Demikian pula pada responden dengan pendidikan rendah. Pendidikan responden yang rendah diiringi pula dengan pengetahuan yang rendah akan bahaya asap rokok selama kehamilan, sehingga tidak terdapat perbedaan antara ibu yang berpendidikan tinggi dengan berpendidikan rendah. Pendidikan ibu tidak berhubungan dengan risiko kelahiran BBLR, demikian pula dengan umur.

Riwayat kelahiran BBLR terdahulu dalam penelitian ini secara statistik bermakna untuk risiko kelahiran BBLR. Kelahiran BBLR pada ibu hamil perokok pasif yang mempunyai riwayat BBLR terdahulu berisiko untuk kelahiran BBLR. Ibu yang mempunyai riwayat pernah melahirkan BBLR cenderung lebih sering untuk melahirkan kembali BBLR dibandingkan dengan ibu yang tidak pernah melahirkan BBLR (25). Faktor medis dan non medis pada kehamilan sebelumnya diduga menjadi penyebabnya. Faktor-faktor tersebut kembali berperan dalam kehamilan selanjutnya. Faktor medis dan non medis ini kadang-kadang tidak dapat diperbaiki, sehingga dibutuhkan perhatian khusus pada kelompok ini terutama bagi ibu perokok pasif yang dapat memperberat risiko kelahiran BBLR.

Kekurangan gizi selama kehamilan yang disertai dengan adanya paparan asap rokok selama kehamilan dapat memperberat penyebab gangguan pertumbuhan janin dalam kandungan. Meningkatkan gizi ibu selama hamil merupakan cara potensial untuk membantu pertumbuhan janin di dalam kandungan. Status gizi ibu yang baik selama kehamilan akan memperlancar suplai oksigen ke janin, sehingga janin menerima cukup oksigen untuk pertumbuhannya. Namun demikian ketercukupan zat-zat gizi janin selama di dalam kandungan juga tergantung dari banyak faktor lain seperti paparan dari asap tembakau (16).
Dalam penelitian ini, status gizi tidak terbukti berpengaruh terhadap BBLR. Paparan asap tembakau yang terus menerus selama kehamilan dapat menurunkan kadar asam folat dalam tubuh ibu. Akibatnya janin juga mengalami kekurangan asam folat (13). Paparan karbonmonoksida dan nikotin yang terus menerus dan penurunan asam folat mengakibatkan gangguan pertumbuhan janin di dalam kandungan. Karena itu ibu hamil dengan status gizi buruk dan terpapar asap rokok selama kehamilan lebih berisiko untuk melahirkan BBLR dibandingkan dengan ibu yang tidak terpapar.

\section{KESIMPULAN DAN SARAN}

Ibu hamil perokok pasif berisiko terhadap kejadian bayi berat lahir rendah. Ibu hamil, baik yang terpapar rokok lebih dari 11 batang maupun hanya 1 sampai 10 batang per hari berisiko lebih tinggi untuk terjadinya bayi berat lahir rendah. Faktor risiko lain yang berperan dapat meningkatkan risiko terjadinya bayi berat lahir rendah pada ibu hamil perokok pasif adalah riwayat BBLR sebelumnya.

Peneliti memberikan beberapa saran untuk mengurangi risiko kelahiran BBLR. Bagi pemerintah dan provider kesehatan sebaiknya materi tentang bahaya asap rokok selama kehamilan hendaknya juga dicantumkan dalam media promosi kesehatan selama kehamilan, seperti pada leaflet untuk ibu hamil, pada poster di klinikklinik pemeriksaan kehamilan, dan buku pegangan ibu hamil.

Pemerintah Aceh diharapkan dapat melakukan sosialisasi atau kampanye tentang bahaya menjadi perokok pasif selama kehamilan, mengingat angka perokok aktif sangat tinggi. Sosialisasi tidak hanya diberikan kepada ibu hamil di klinik-klinik kehamilan, tetapi ditujukan kepada setiap masyarakat terutama di tempat-tempat umum agar para perokok aktif dapat mematikan rokoknya selama berada di antara ibu hamil.

Bagi provider kesehatan disarankan dapat menjelaskan tentang bahaya asap rokok selama kehamilan. Bahaya menjadi perokok pasif selama kehamilan hendaknya dijadikan salah satu materi konseling pada saat pemeriksaan kehamilan. Provider kesehatan dapat memberikan konseling tentang bahaya paparan asap rokok, materi tentang bahaya paparan asap rokok hendaknya dimasukkan dalam kurikulum pada tiap sekolah-sekolah kesehatan.

Ibu hamil diharapkan dapat menghindari asap rokok selama kehamilan, terutama ibu dengan riwayat BBLR pada persalinan sebelumnya dan ibu hamil dengan status gizi buruk. Bila para perokok aktif yang tinggal serumah dengan ibu hamil tidak dapat menghentikan kebiasaan merokok, disarankan agar tidak merokok selama berada di dekat ibu hamil terutama di dalam rumah. 


\section{RUJUKAN}

1. United Nations Children's Fund and World Health Organization. Low birth weight: country, regional and global estimate [serial online] 2004 [cited 2006 Des 08]. Avaliable from: www.who.int.

2. Lawnn JE, Brian JM, Ross SR. The healthy newborn, a reference manual for program managers. Atlanta: CDC,CCHI,Care; 2006.

3. Trading economics. Low-birthweigth babies (\% of births) in Indonesia [serial online] 2009 [cited 2009 Oct 09]. Avaliable from: www.trading economics.com

4. Chen PJ. Labour and delivery - low birth weigth [serial online] 2008 [cited 2009 Oct 09]. Avaliable from: www. umm.edu

5. WHO. Development of strategy towards promoting optimal fetal growth [serial online] 2007 [cited 2007 Dec 10]. Available from: www.who.int/nutrion/topics/ feto_maternal

6. Ikatan Dokter Anak Indonesia. Bayi berat lahir rendah dalam standar pelayanan medis kesehatan anak edisi I. Jakarta: Ikatan Dokter Anak Indonesia; 2004.

7. United Nation. The millennium development goals report. New York: UN Department of Public Information; 2005.

8. Andarwati R, Prawirohartono EP, Gamayanti IL. Hubungan berat badan lahir, pemberian ASI eksklusif, status gizi, dan stimulasi kognitif dengan kecerdasan anak usia 5-6 tahun. Jurnal Gizi Klinik Indonesia 2006; 2(3): 95-100.

9. Weisglas-Kuperus N, Baerts W, Smrkovsky M, Sauer PJJ. Effect of biological and social factors on the cognitive development of very birth weight children. Pediatrics 1993; 92:658-65.

10. Woodruff TJ, Parker JD, Darrow LA, Slama R, Bell ML, Choi H, Glinianaia S, Hoggatt KJ, Karr CJ, Lobdell DT, Wilhelm M. Methodological issues in studies of air pollution and reproductive health. Environ Res 2009; 109:311-20.

11. Depkes RI. Riset kesehatan dasar 2007. Badan Litbang kesehatan Departemen Kesehatan RI. Jakarta: Depkes RI; 2008.

12. Bell ML, Ebisu K, Belanger K. Ambient air pollution and low birth weight in Connecticut and Massachusetts. Environ Health Perspect 2007; 115:1118-24.

13. Mangoenprasodjo SA, Hidayati NS. Hidup sehat tanpa asap rokok. Yogyakarta: Pradipta Publishing; 2005.
14. Ward C, Lewis S, Coleman T. Prevalence of maternal smoking and environmental tobacco ekposure during pregnancy and impact on birth weigth: retrospective study using millenium cohort. BMC Public Health 2007; 7: 81.

15. Pogodina C, Brunner HLR, Racine EF, Platonova E. Smoke-free homes for smoke-free babies: the role of residential environtmental tobacco smoke on low birth weigth. J Comunity Health 2009; 34(5): 37682.

16. Salmasi G, Grady R, Jones J, McDonald SD. Knowledge synthesis group. Acta Obstet Gynecol Scand 2010; 89(4); 423-41.

17. Fatunzi G, Vaccaro V, Aggazoti G, Righi E, Kanitz S, Barbone F, Sansebastiano G, Bttaglia MA, leoni V, Fabiani L, Sciacca S, Facchinetti F. Exposure to active and passive smoking during pregnancy and severe small for gestational age term. J Matern Fetal Neonatal Med 2008; 21(9): 643-7.

18. Lemeshow S, Hosmer JR, Klar J. Adequacy of sample size in health studies. Pramono D, Kusnanto H. 1997 (Alih bahasa). Yogyakarta: Gadjah Mada University Press; 1997.

19. Jarvis MJ. Children's exposure to passive smoking: survey methodology and monitoring trends. London: WHO, NCD, TFI.11;1999.

20. Mickey J, Greenland S. A study of the impact of counfounder selection criteria on effect estimation. Am J Epid 1989; 129: 125-37.

21. Kharrazi M, Delorenze GN, Kaufman FL, Eskenazi B, Bernet JT Jr, Graham S, Pearl M, Pirkle J. Environmental tobacco smoke and pregnancy outcome. Epidemiology 2004; 15(6): 660-70.

22. Stillman RJ, Rosenberg MJ, Sachs BP. Smoking and reproduction. Fertil and Sterility 1986; 46: 545-66.

23. Shah $P$, Ohlsson $A$. Literature review of low birth weigth, including small for gestational age and preterm birth. Toronto: Departement of Pediatrics Mount Sinai Hospital, Toronto Public Health; 2002.

24. Lindbohm, Taskinen. Reproductive hazard in the workplace. London: Women and Health, Academic Press; 2000.

25. Krol M, Florek E, Kornacka, Bokiniec R, Piekoszewski W. Clinical condition of the newborn versus tobacco smoke exposure during fetal life. Przegl Lek 2009; 66(10): 548-53. 